\title{
The Effect of Hypnotherapy on Depression, Anxiety, and Stress, in People Living with HIV/AIDS, in "Friendship Plus" Peer Supporting Group, in Kediri, East Java
}

\author{
Ahmad Wasis Setyadi'), Bhisma Murti²), Argyo Demartoto3) \\ 1)Masters Program of Public Health, Universitas Sebelas Maret \\ 2)Faculty of Medicine, Universitas Sebelas Maret \\ 3)Faculty of Social and Political Sciences, Universitas Sebelas Maret
}

\begin{abstract}
Background: Human Immunodeficiency Virus/ Acquired Immunodeficiency Syndrome (HIV/ AIDS) is a global public health problem. Identification of HIV infection can cause psychological distress to the affected, such as depression, anxiety, and stress. The deeper distress people living with HIV/AIDS (PLWH), the weaker immunity, the stronger virus attact. This study aimed to test the effectiveness of hypnotherapy on the reducing depression, anxiety, and stress, in PLWH at Friendship Plus peer supporting group in Kediri.

Subjects and Method: This was a Randomized Controlled Trial (RCT) conducted in Kediri, East Java. A total sample of 6o PLWH were randomized into hypnotherapy group $(\mathrm{n} 1=30)$ and control group $(\mathrm{n} 2=30)$. Hypnotherapy was provided 4 times per months. The levels of depression, anxiety, and stress, were measured before and after the intervention, using Depression Anxiety Stress Scale (DASS) 42, which was translated in Indonesian. The mean differences in the 3 outcome variables between the hypnotherapy and the control groups were tested by t test.

Results: After the intervention, the level of the depression in the hypnotherapy group (mean= 5.07; $\mathrm{SD}=5.45$ ) was lower than that in the control group (mean=17.73; $\mathrm{SD}=6.50$ ), and it was statistically significant ( $\mathrm{p}<0.001)$. The level of the enxiety in the hypnotherapy group ( $\mathrm{mean}=7.70$; $\mathrm{SD}=5.29$ ) was lower than that in the control group (mean= 20.77; $\mathrm{SD}=5.98$ ), and it was statistically significant ( $\mathrm{p}<0.001)$. The level of the stress in the hypnotherapy group (mean= 7.77; $\mathrm{SD}=6.37$ ) was lower than that in the control group (mean= 20.30; $\mathrm{SD}=5.34$ ), and it was statistically significant $(\mathrm{p}<0.001)$. The level of DASS combined in the hypnotherapy group (mean= 20.53; $\mathrm{SD}=15.30$ ) was lower than that in the control group (mean=58.80; $\mathrm{SD}=15.63$ ), and it was statistically significant $(\mathrm{p}<0.001)$.
\end{abstract}

Conclusion: Hypnotherapy is effective in reducing depression, anxiety, stress, and DASS combined in PLWH.

Keywords: depression, anxiety, stress, DASS, PLWH

\section{Correspondence:}

Ahmad Wasis Setyadi. Masters Program in Public Health, Universitas Sebelas Maret. Jl. Ir. Sutami 36A, Surakarta 57126, Central Java. Email: ahmadwasis@gmail.com.

\begin{tabular}{l} 
BACKGROUND \\
\hline Human Immunodeficiency Virus/ Acqu- \\
ired Immunodeficiency Syndrome (HIV/- \\
AIDS) is a major global health issue with \\
more than 34 million people dying (WHO, \\
2015). When someone diagnosed with HIV, \\
he/she will experience psychological pro- \\
blems such as refusal, anger, shock, and
\end{tabular} depression. These psychological symptoms make him/her more stressful in living life (Ministry of Health RI, 2014). In addition, psychosocial burden cause anxiety, depression, lack of confidence, despair, even the desire to do commit suicide (Sriati, 2013). In the Epidemiologic Triangle at the Host level, there are psychological pro- 
blems which can be fatal in decreasing immune system if it is not immediately handled. As a result, viruses can attack without any significant resistance.

At the end of 2014, around 3.2-3.7 million people were living with HIV. At the end of 2014, there were 200,000-250,000 new people in the world infected by HIV virus (WHO, 2015). The World Health Organization (WHO) had estimated 9 out of 10 people who infected with HIV came from developing countries (WHO, 2015).

The case of HIV / AIDS in Indonesia was first discovered in Bali in 1987. The cumulative number of HIV sufferers from 1987 to September 2014 was 150.296 people, while the cumulative total in AIDS cases was 55.799 people. The highest cumulative number of HIV infection cases was DKI Jakarta Province (32.782 cases). East Java was in the second place with 19.249 cases, followed by Papua, West Java, Bali, North Sumatra, Central Java, West Kalimantan, Riau Islands and South Sulawesi. The highest cumulative number in East Java was Surabaya city with 2,030 cases. In addition, Malang regency had 1,058 cases, Jember Regency had 750 cases, and Sampang regency had 4 cases (Ministry of Health RI, 2015).

There were 341 sufferers of HIV/ AIDS in Kediri Regency, East Java, who had received mentoring with the criteria of 153 men and 178 women. The highest risk factors for infection are high-risk partners (35\%), high-risk men (36\%), female sex workers (18\%), same-sex men (10\%), and transvestites (1\%) (Kediri Regency Health Office, 2014). The total number in Kediri District Health Office, 2014, is the same as the data in "Friendship Plus" Peer Supporting Group in Kediri, which is 341 people living with HIV/AIDS. The new members who participated actively in "Friendship Plus" Peer Supporting Group in Kediri in
2014 to 2016 were 74 people. This study was conducted in "Friendship Plus" Peer Supporting Group in Kediri because it was the third highest HIV / AIDS case in East Java after Surabaya and Malang..

HIV/AIDS has not been fully accepted as other diseases in general, so that who are experiencing HIV/AIDS (PLWH) must bear the heavier burden, not only the HIV intervention into their bodies but also the psychological burden due to stigma and discrimination (Sriati, 2013). The discriminatory treatment shown by the community to PLWH creates deeper psychological burden (Hawari, 2012). The experience from several countries shows that continuous care service from hospital to home must be optimized for those who are infected to improve their quality of life (WHO, 2015). However, most of PLWH families usually feel afraid of infecting HIV/AIDS if they often contact, thus it will make the psychological burden of PLWH is getting worse (Sriati, 2013).

The way to overcome depression, anxiety and stress is by adaptation which aims to change and accept the situation and condition happens in life (Rafael, 2015). If the coping mechanism is successful, the person will be able to adapt to the change. Hypnotherapy is one of the proven and effective methods for dealing with stress (Rafael, 2015).

From the description above, the researcher was interested in conducting further study on the effect of hypnotherapy on the changes in depression, anxiety and stress in people living with HIV/AIDS (PLWH) in "Friendship Plus" Peer Supporting Group, Kediri. This study aimed to analyze the effect of hypnotherapy on the changes in depression, anxiety and stress in people living with HIV/AIDS (PLWH) in "Friendship Plus" Peer Supporting Group, Kediri. 
Journal of Health Promotion and Behavior (2016), 1(2): 100-109

https://doi.org/10.26911/thejhpb.2016.01.02.05

The study result conducted by Untas et al. (2013) showed that depression in hemodialysis patients decreased after hypnotherapy. A study conducted by $\mathrm{Lu}$ and $\mathrm{Lu}$ (2013) also showed that hypnosis therapy could decrease anxiety levels and increase calmness in patients when doing acupuncture. From these results, it can be concluded that the use of hypnotherapy can alleviate and find a solution to the psychological burden suffered by PLWH. Therefore, the depression, anxiety, and stress in PLWH can decrease.

There are several methods besides hypnotherapy that are used to deal with stress but they are less effective and take a long time to feel the significant changes. It is because other methods do not lead to the root of the problem and only at the conscious mind level (Kelwandi, 2015).

\section{SUBJECTS AND METHOD}

One of the strategies to make both groups comparable is allocating subjects randomly (RCT) (Murti, 2013). According to Rajagopalan (2013), randomized controlled trial (RCT) design is an observation study where the subjects in a population are randomly allocated into groups. The population in this study were 74 people and afterwards 30 people were taken randomly for the intervention group (hypnotherapy) and 30 people for the control group (non hypnotherapy).

Variables of depression, anxiety and stress use questionnaires of Depression Anxiety Stress Scale (DASS) by Lovinbond (1995). It was carried out before and after treatment towards intervention and control groups. The results of DASS were analyzed using an independent $t$ test.

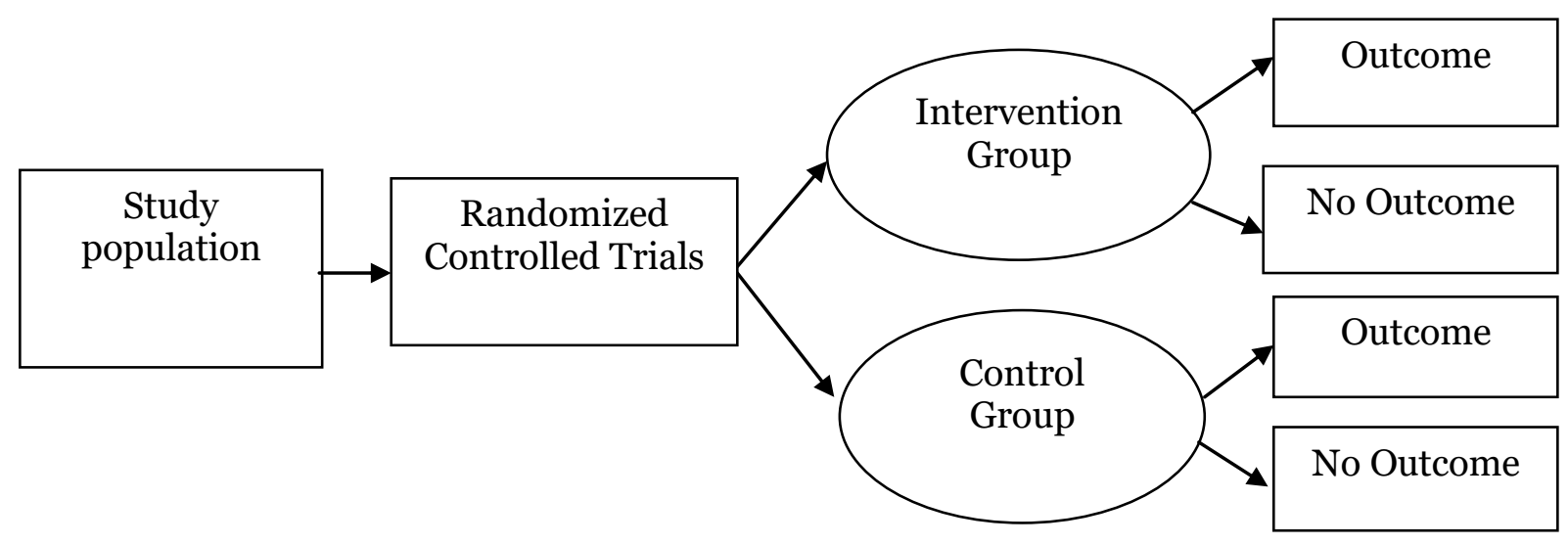

\section{Figure 1. The Sampling Technique}

The study had been carried out in Kediri with the consideration that the incidence of people living with HIV / AIDS (PLWH) in Kediri, East Java, was still high. This study conducted in "Friendship Plus" Peer Supporting Group, Kediri, in July to November 2016. The independent variable was hypnotherapy, while the dependent variables were depression, anxiety, and stress. The method used to control con- founding variables was by randomizing the sampling, so that the composition of the intervention and control groups could be the same.

\section{RESULT}

The study subjects in this study were 60 people: 27 men and 33 women. There were 8 people in the age of $<20$ years, 49 people 
in the age of 20-35 years, 3 people in the age of $>35$ years.

Based on the education level, there were 37 people from basic education and 23 people from secondary education. Based on the income, there were 25 people with $\geq$ minimum wage and 35 people with $<$ minimum wage. Based on the occupation, there were 2 civil servants, 5 traders, 2 entrepreneurs, 20 laborers, 31 unemployed people.

Table 1. The characteristic of study subject

\begin{tabular}{|c|c|c|}
\hline \multirow{2}{*}{ Characteristic } & \multicolumn{2}{|c|}{ Study subject } \\
\hline & $\mathbf{n}$ & $\%$ \\
\hline \multicolumn{3}{|l|}{ Gender } \\
\hline Man & 27 & $(45.0 \%)$ \\
\hline Woman & 33 & $(55.0 \%)$ \\
\hline \multicolumn{3}{|l|}{ Age of study subject } \\
\hline$<20$ years & 8 & $(13.3 \%)$ \\
\hline $20-35$ years & 49 & $(81.7 \%)$ \\
\hline$>35$ years & 3 & $(5.0 \%)$ \\
\hline \multicolumn{3}{|l|}{ Education } \\
\hline Basic Education (low) & 37 & $(61.7 \%)$ \\
\hline Secondary Education (high) & 23 & $(38.3 \%)$ \\
\hline \multicolumn{3}{|l|}{ Income } \\
\hline$\geq$ minimum wage & 25 & $(41.7 \%)$ \\
\hline$<$ minimum wage & 35 & $(58.3 \%)$ \\
\hline \multicolumn{3}{|l|}{ Occupation } \\
\hline Civil servant & 2 & $(3.3 \%)$ \\
\hline Trader & 5 & $(8.3 \%)$ \\
\hline Entrepreneur & 2 & $(3.3 \%)$ \\
\hline Laborer & 20 & $(33.3 \%)$ \\
\hline Unemployed & 31 & $(51.7 \%)$ \\
\hline
\end{tabular}

Table 2. The description of hypnotherapy variable

\begin{tabular}{lccc}
\hline & Intervention & Frequency (n) & Percentage (\%) \\
\hline No & 30 & $50 \%$ \\
Yes & 30 & $50 \%$ \\
Total & 60 & $100 \%$ \\
\hline
\end{tabular}

Based on the description result of hypnotherapy, there were 60 samples: 30 study subjects $(50 \%)$ were given hypnotherapy intervention and 30 study subjects (50\%) were not given hypnotherapy intervention.

Based on table 3, during the pre test, the highest number of study subject were in moderate depression category with 26 study subjects (43.3\%). Meanwhile, during the post test, the highest number of study subject were in normal category with 30 study subjects (50\%).
Based on table 4, during the pre test, the highest number of study subject were in moderate anxiety category with 33 study subjects (55\%). Meanwhile, during the post test, the highest number of study subject were in normal category with 24 study subjects (40\%).

Based on table 5, during the pre test, the highest number of study subject were in moderate stress category with 36 study subjects (60\%). Meanwhile, during the post test, the highest number of study subject were in mild category with 22 study subjects (36.7\%). 
Journal of Health Promotion and Behavior (2016), 1(2): 100-109

https://doi.org/10.26911/thejhpb.2016.01.02.05

Bivariate analyis showed the effect of one independent variable on one dependent variable such as depression, anxiety, and stress using independent $t$ test.

Table 3. The description of depression variable

\begin{tabular}{lcccc}
\hline \multirow{2}{*}{ Depression } & \multicolumn{2}{c}{ Pre test } & \multicolumn{2}{c}{ Post test } \\
\cline { 2 - 5 } & Frequency (n) & Percentage (\%) & Frequency (n) & Percentage (\%) \\
\hline Normal & 8 & $13.3 \%$ & 30 & $50 \%$ \\
Mild & 24 & $40 \%$ & 14 & $23.3 \%$ \\
Moderate & 26 & $43 \cdot 3 \%$ & 15 & $25.0 \%$ \\
Severe & 2 & $3.3 \%$ & 1 & $1.7 \%$ \\
Very severe & 0 & $0 \%$ & 0 & $0 \%$ \\
Total & 60 & $100 \%$ & 60 & $100 \%$ \\
\hline
\end{tabular}

Table 4. The description of anxiety variable

\begin{tabular}{lcccc}
\hline \multirow{2}{*}{ Anxiety } & \multicolumn{2}{c}{ Pre test } & \multicolumn{2}{c}{ Post test } \\
\cline { 2 - 5 } & Frequency (n) & Percentage (\%) & Frequency (n) & Percentage (\%) \\
\hline Normal & $\mathrm{O}$ & $\mathrm{O} \%$ & 24 & $40 \%$ \\
Mild & 27 & $45 \%$ & 19 & $31.7 \%$ \\
Moderate & 33 & $55 \%$ & 15 & $25 \%$ \\
Severe & $\mathrm{O}$ & $\mathrm{O} \%$ & 2 & $3.3 \%$ \\
Very severe & $\mathrm{O}$ & $\mathrm{O} \%$ & 0 & $0 \%$ \\
Total & 60 & $100 \%$ & 60 & $100 \%$ \\
\hline
\end{tabular}

Table 5. The description of stress

\begin{tabular}{lcccc}
\hline \multirow{2}{*}{ Stress } & \multicolumn{2}{c}{ Pre test } & \multicolumn{2}{c}{ Post test } \\
\cline { 2 - 5 } & Frequency (n) & Percentage (\%) & Frequency (n) & Percentage (\%) \\
\hline Normal & 2 & $3.3 \%$ & 18 & $30 \%$ \\
Mild & 22 & $36.7 \%$ & 22 & $36.7 \%$ \\
Moderate & 36 & $60 \%$ & 20 & $33.3 \%$ \\
Severe & 0 & $0 \%$ & 0 & $0 \%$ \\
Very severe & 0 & $0 \%$ & 0 & $0 \%$ \\
Total & 60 & $100 \%$ & 60 & $100 \%$ \\
\hline
\end{tabular}

Table 6. The result of independent $t$ test of mean differences on depression, anxiety, and stress before hypnotherapy between hypnotherapy group and nonhypnotherapy groups

\begin{tabular}{lccccccc}
\hline \multicolumn{1}{c}{$\begin{array}{c}\text { Independent } \\
\text { Variable }\end{array}$} & \multicolumn{3}{c}{ Hypnotherapy } & \multicolumn{3}{c}{ Non-hypnotherapy } & \multirow{2}{*}{ p } \\
\cline { 2 - 7 } & Mean & SD & n & Mean & SD & \\
\hline Depression & 30 & 17.53 & 6.62 & 30 & 17.40 & 6.56 & $<0.938$ \\
Anxiety & 30 & 20.53 & 5.88 & 30 & 20.37 & 6.00 & $<0.914$ \\
Stress & 30 & 20.00 & 5.41 & 30 & 20.07 & 5.46 & $<0.962$ \\
Combination (DAS) & 60 & 58.13 & 15.82 & 60 & 57.77 & 15.87 & $<0.926$ \\
\hline
\end{tabular}

Table 6 presented a bivariate analysis of depression, anxiety, and stress in the hypnotherapy group and non-hypnotherapy group before treatment. Based on the result, the $\mathrm{p}$ value was $<0.938$ for depression in PLWH who received hypnotherapy and did not receive hypnotherapy. It showed that there was no effect of hypnotherapy on depression during the pre test. It also showed a mean of 17.53 in the hypnotherapy group and 17.40 in the control group / non-hypnotherapy.

The $\mathrm{p}$ value was $<0.914$ for anxiety in PLWH who received hypnotherapy and did 
not receive hypnotherapy. It showed that there is no effect of hypnotherapy on anxiety during the pre test. It also showed a mean of 20.53 in the hypnotherapy group and 20.37 in the control group / nonhypnotherapy.

The $\mathrm{p}$ value was $<0.962$ for stress in PLWH who received hypnotherapy and did not receive hypnotherapy. It showed that there is no effect of hypnotherapy on stress during the pre test. It also showed a mean of 20.00 in the hypnotherapy group and

Table 7. The result of independent $t$ test of mean differences on depression, anxiety, and stress after hypnotherapy between hypnotherapy group and nonhypnotherapy groups

\begin{tabular}{lccccccc}
\hline \multirow{2}{*}{ Variable } & \multicolumn{3}{c}{ Hypnotherapy } & \multicolumn{3}{c}{ Non-hypnotherapy } & \multirow{2}{*}{ p } \\
\cline { 2 - 7 } & $\mathbf{n}$ & Mean & SD & n & Mean & SD & \\
\hline Depression & 30 & 5.07 & 5.45 & 30 & 17.73 & 6.50 & $<0.001$ \\
Anxiety & 30 & 7.70 & 5.29 & 30 & 20.77 & 5.98 & $<0.001$ \\
Stress & 30 & 7.77 & 6.37 & 30 & 20.30 & 5.34 & $<0.001$ \\
Combination (DAS) & 60 & 20.53 & 15.30 & 60 & 58.80 & 15.63 & $<0.001$ \\
\hline
\end{tabular}

Table 7 presented a bivariate analysis of depression, anxiety, and stress in the hypnotherapy group and non-hypnotherapy group after treatment. Based on the result, the $\mathrm{p}$ value was $<0.001$ for depression in PLWH who received hypnotherapy and did not receive hypnotherapy. It showed that there was an effect of hypnotherapy on depression during the post test. It also showed a mean of 5.07 in the hypnotherapy group and 17.73 in the control group / nonhypnotherapy.

The $\mathrm{p}$ value was $<0.001$ for anxiety in PLWH who received hypnotherapy and did not receive hypnotherapy. It showed that there is an effect of hypnotherapy on anxiety during the post test. It also showed a mean of 7.70 in the hypnotherapy group and 20.77 in the control group / nonhypnotherapy.

The $\mathrm{p}$ value was $<0.001$ for stress in PLWH who received hypnotherapy and did not receive hypnotherapy. It showed that there is an effect of hypnotherapy on stress
20.07 in the control group / non-hypnotherapy.

The $\mathrm{p}$ value was $<0.926$ for combination (depression, anxiety, and stress) in PLWH who received hypnotherapy and did not receive hypnotherapy. It showed that there is no effect of hypnotherapy on depression during the pre test. It also showed a mean of 58.13 in the hypnotherapy group and 15.87 in the control group / non- hypnotherapy. during the post test. It also showed a mean of 7.77 in the hypnotherapy group and 20.30 in the control group/non-hypnotherapy.

The $p$ value was $<0.001$ for combination (depression, anxiety, and stress) in PLWH who received hypnotherapy and did not receive hypnotherapy. It showed that there is an effect of hypnotherapy on depression, anxiety, and stress during the post test. It also showed a mean of 20.53 in the hypnotherapy group and 58.80 in the control group / non- hypnotherapy.

\section{DISCUSSION}

\section{The effect of hypnotherapy on depression level in PLWH}

Table 7 showed that there was an effect of hypnotherapy on depression during the post test. It showed that PLWH who were given hypnotherapy had a decrease of depression level compared to PLWH who were not given hypnotherapy. This is in line with the study conducted by Untas et al. 
(2013) and Shih et al, (2010) which stated that the depression on a patient could decrease after hypnotherapy. It showed that hypnotherapy could be an alternative in pharmacological treatment to decrease depression level.

It was concluded that there was an effect of hypnotherapy towards depression level. There was a decrease of depression level in PLWH during the post test in the intervention group.

\section{The effect of hypnotherapy on anxiety level in PLWH}

Table 7 showed that there was an effect of hypnotherapy on anxiety during the post test. It showed that PLWH who were given hypnotherapy had a decrease of anxiety level compared to PLWH who were not given hypnotherapy. This is in line with the study conducted by Lu and Lu (2013) which stated that hypnotherapy could decrease the anxiety level and increase the calmness on patient. Two groups of students had a high score on the anxiety test questionnaires that were treated by desensitization under hypnosis or desensitization after relaxation training with biofeedback. Both groups showed a significant decrease in anxiety after treatment compared to the noncontact control group ( $p>0.05$ ) (Spies, 2011).

It was concluded that there was an effect of hypnotherapy towards anxiety level. There was a decrease of depression level in PLWH during the post test in the intervention group.

\section{The effect of hypnotherapy on stress level in PLWH}

Table 7 showed that there was an effect of hypnotherapy towards stress level during the post test. It showed that PLWH who were given hypnotherapy had a decrease of stress level which more significant than those who were not given hypnotherapy.
Relaxation with hypnotherapy makes the immune system better. When the mind is relaxed and positive, it will make the positive hormones level, high enzymes, and normal blood pressure. Relaxation can deliver impulses along the pressure path to make someone feel good. Many studies have linked relaxation with longevity and show that there are lost of health benefits in relaxation. It is not only to find peace in daily routine, but also to keep planning activities for the future (Rafael, 2015).

Disimpulkan bahwa terdapat pengaruh hipnoterapi terhadap tingkat stres. Pada kelompok intervensi saat dilakukan post test ODHA mempunyai penurunan tingkat stres.

The clinical hypnotherapy application is able to decrease post-traumatic stress disorder and overcome dissociative experiences during and after trauma (Gunawan, 2014). According to Kingsbury (2011), hypnosis can decrease posttraumatic stress disorder (PTSD).

It was concluded that there was an effect of hypnotherapy on stress. There was a decrease of depression level in PLWH during the post test in the intervention group.

\section{The effect of hypnotherapy on the changes in depression, anxiety, and stress in PLWH}

Table 7 showed that there was an effect of hypnotherapy on depression, anxiety, and stress during the post test. It showed that PLWH who were given hypnotherapy had a decrease of depression, anxiety, and stress level which was significant compared to PLWH who were not given hypnotherapy.

Hypnotherapy is one of the therapies to decrease depression, anxiety and stress level through a calm system in the human brain; so, when the brain receives a positive response, the hypothalamus will secrete endorphins and enkephalin as painkillers 
and control of CRF secretion. When CRF secretion decreases, ACTH secretion is also stable and controlled. In addition, a decrease of ACTH will stimulate a decrease in cortisol and catecholamine production which increase the immune response (Djauzi and Djoerban, 2011). The time needed for the hypnosis result is immediately after hypnosis until the environment affects again; if the environment has a positive synergy, the results of hypnosis can last longer (Rafael, 2015).

There is an effect of hypnotherapy on depression level in PLWH during pre-test and post-test in "Friendship Plus" Peer Supporting Group in Kediri ( $\mathrm{p}<\mathrm{0.001)}$. There is an effect of hypnotherapy towards anxiety in PLWH during pre-test and posttest in "Friendship Plus" Peer Supporting Group in Kediri ( $p<0.001)$. There is an effect of hypnotherapy towards stress level in PLWH during pre-test and post-test in "Friendship Plus" Peer Supporting Group in Kediri $(p<0.001)$.

\section{REFERENCE}

$\overline{\text { American Psychiatric Association (2000). }}$ American Psychiatric Association Diagnostic and Statistical Manual of Mental Disorders, 4th Edition.

Blum J, Kochs E, Forster N, Schneider G (2006). The Influence of Injection Rate on the Hypnotic Effect of Propofol during Anesthesia: A Randomized Trial.Journal of clinical. (3): e17.

Deeley Q, Walsh E, David A, Oakley BV, Koppe C, Mehta MA, Halligan PW (2013). Using hypnotic suggestion to model loss of control and awareness of movements: An exploratory fMRI Study.Journal of clinical. PLoS ONE 8(10): e 78324.

Depkes RI (2012). Panduan Tatalaksana Klinis Infeksi HIV pada orang Dewasa dan Remaja. Jakarta: Departemen
Kesehatan Republik ndonesia Direktorat Jenderal Pengendalian Penyakit dan Penyehatan Lingkungan.

Depkes RI (2014). Buku HIV/AIDS untuk SPK/AKPER. Jakarta: Departemen Kesehatan RI Pusat Pendidikan Tenaga Kesehatan.

Depkes RI (2015). Data Kasus HIV/AIDS di Indonesia. Jakarta: Direktorat Jendral PM2PL.

Dillinger (2011). Nursingcare of patients with HIV Disease and AIDS. Philadelphia: Davis Company.

Dinkes Kabupaten Kediri(2014). Jumlah Penderita HIV/AIDS.www.dinkeskab. kediri.co.id.

Djauzi, Djoerban Z(2011). Buku Ajar Ilmu Penyakit Dalam. Jakarta: Pusat Penerbit Departemen Ilmu Penyakit Dalam FKUI.

Gallant (2011). 100 Tanya Jawab mengenai HIV dan AIDS. Alih bahasa: Alexander Sindoro. Jakarta: Indeks.

Gunawan AW (2014). BuktiIlmiah Manfaat Hipnoterapi, Pendidikan serta Kualifikasi Praktisi Hipnoterapi.

HandayaniS (2012). Peran Dukungan Sebaya Terhadap Mutu Hidup Odha Di Indonesia.

Hawari (2012). Manajemen stres, cemas, dan depresi. Jakarta: Balai Penerbit FK UI.

Hickie I, Naismith S, Ward P, Turner K, Scott E, Mitchell P, Wilhelm K (2005). Reduced hippocampal volumes and memory loss in patients with early- and late-onset depression. The British Journal of Psychiatry. 186(3): 197-202.

Kemenkes RI (2014). infoDATIN, Pusat Data dan Informasi Kementerian Kesehatan RI, Situasi dan Analisis HIV AIDS.www.depkes.go.id.

Kingsbury SJ (2011). Hypnosis in the Treatment of Posttraumatic Stress Disor- 
Journal of Health Promotion and Behavior (2016), 1(2): 100-109

https://doi.org/10.26911/thejhpb.2016.01.02.05

der: An Isomorphic Intervention. Americanof JournalClinical Hypnosis.31(2).

Lu DP (2013). A Comparison of the Clinical Effectiveness of Various Acupuncture Points in Reducing Anxiety to Facilitate Hypnotic Induction.Journal of Clinical and Experimental Hypnosis.

Lu DP, Lu PG (2001). Acupuncture and Clinical Hypnosis for Facial and Head and Neck Pain: A Single Crossover Comparison. American Journal of Clinical Hypnosis. 44(2).

Lovinbond SH, Lovinbond PF (1995). Manual for the Depression Anxiety Stress Scale. The Psychology Foundation of Australia Inc.

Murti B (2013). Desain Dan Ukuran Sampel Untuk Penelitian Kuantitatif Dan Kualitatif Di Bidang Kesehasatan. Cetakan ketiga, Februari 2013. ISBN 979-420-806. Gajah Mada University Press.

Najmah (2015). Epidemiologi untuk Mahasiswa Kesehatan Masyarakat. Depok: Rajawali Pers.

Nasronudin (2012). HIV \& AIDS Pendekatan Biologi dan Molekuler, Klinis, Dan Sosial. Surabaya: Airlangga University Press.

Nevid JS, Rathus SA (2005). Psikologi Abnormal, Fifth Edition. Penerjemah (Tim Fakultas Psikologi UI: Murad, J. dkk). Jakarta: Penerbit Erlangga.

Nisa H (2007). Epidemiologi Penyakit Menular. Jakarta : Lembaga penelitian UIN.

Narsy N (2008). Epidemiologi. Jakarta: PT RINEKA CIPTA.

Parwati D (2011). Respon Imun Inveksi HIV Dalam: Buku Ajar Ilmu Penyakit Dalam Edisi Keempat - Jilid I. Jakarta: Pusat Penerbitan Departemen Ilmu Penyakit Dalam FKUI.
Psysichology Foundation of Australia (2014). Depression Anxiety Stress Scale. www.psy.unsw.edu.su. Retrieved on Juli 20, 2016.

Rafael R (2015). Bagaimana Cara Mengatasi Stres. www.romyrafael.net.

Rajagopalan R, Deodurg PM, Srikanth (2013). Overview of randomized controlled trials. Asian Journal of Pharmaceutical And Clinical Research. ISSN-0974-2441. 6 (3).

Robbins (2011). Perilaku Organisasi. Jakarta: Salemba Empat.

Rush AJ, Adli M, Bauer M (2006). Algorithms and Collaborative-care System for Depression : are they effective and why? A systematic review, Biol Psychiatry, 59.

Rusli SI, Wijaya JA (2009). The Secret of Hypnosis, penebar Plus, Jakarta.

Sadock BJ, Sadock VA, Sadock's K (2007). Synopsis of Psychiatry. Behavior Sciences/Clinical Psychiatry. 10th 2. Wagner KD, Brent DA. Depressive Disorders and Suicide.

Santos Y (2012). Intermediete Hypnotherapy. Buku panduan resmi NLP.

Saryono (2011). Penelitian Kualitatif dalam Kesehatan. Yogyakarta: Nuha Medika.

Shenefelt PD (2013). Anxiety Reduction using Hypnotic Induction and SelfGuided Imagery for Relaxation during Dermatologic Procedures. Journal of Clinical and Experimental Hypnosis.

Shih M, Yang YH, Koo M (2011). A MetaAnalysis of Hypnosis in the Treatment of Depressive Symptoms: A Brief Communication.International Journal of Clinical and Experimental Hypnosis. 57(4).

Smeltzer Sc, Bare B, Hinkle JL, Cheever KH (2012). Bruner \& Suddarth's Textbook of Medical Surgical Nursing. 
Soedarmadji B (2013). Psikologi Konseling. Jakarta: Kencana Prenada Media Group.

Spies G (2011). Desensitization of test anxiety: Hypnosis compared with biofeedback. American Journal of Clinical Hypnosis. 22(2).

Sriati (2013). Pengertian Stres. www.akademik.unsri.ac.id.

Stuart GW, Sundeen SJ (2007). Buku Saku Keperawatan Jiwa, Edisi 5. Jakarta; EGC.

Summer (2010). Inclusion and Exclusion Criteria.www.unm.edu.

Suwandi A (2015). Mahir menghipnotis cepat dan instan turbo speed hipnotis. Jakarta: Spasi Media.

Untas A (2013). The effects of hypnosis on anxiety, depression, fatigue, and sleepiness in people undergoing hemodialysis. Journal of Clinical and
Experimental hypnosis. www.ncbi.nlm.nih.gov.

Videbeck, Sheila L (2008). Buku Ajar Keperawatan Jiwa. Jakarta: EGC.

Wangsadjaja R (2014). Stres.Artikel Psikologi. www.psycoshare.com.

Kevin W (2011). Pengantar Sosiologi Kesehatan dan Penyakit. Jakarta: Rajawali Press.

WHO (2015). HIV/AIDS. www.who.int. Retrieved on Juli 2O, 2016.

WHO (2016). Depression.www.who.int. Windalfin. (2013). Bahaya Hipnotis. Artikel Psikologi.www.indomind.com.

Yapko M (2011). Hypnosis in Treating Symptoms and Risk Factors of Major Depression. American Journal of Clinical Hypnosis.44(2).

YayasanSpiritia (2016). Kelompok Dukungan Sebaya.www.spiritia.or.id. 